\title{
A new dibromotyrosine-derived metabolite from the sponge Psammalplysilla purpurea
}

\author{
K. Ravinder, A.Vijender Reddy, T.V. Raju, and Y. Venkateswarlu* \\ Natural Products Laboratory, Organic Chemistry Division-I \\ Indian Institute of Chemical Technology Hyderabad 500 007, India \\ E-mail: luchem@,iict.res.in
}

\section{Dedicated to Dr. A. V. Rama Rao to mark his $70^{\text {th }}$ birthday and contribution ${ }^{1}$ \\ (received 11 Jun 04; accepted 23 Sep 04; published on the web 26 Sep 04)}

\begin{abstract}
A new dibromo tyrosine-derived metabolite $N$-(\{3,5-dibromo-4-[3-(methylamino) propoxy]phenyl \} ethyl) carbamic acid methyl ester (1) and a known dibromotyrosine derivative purpuramine-L (2) have been isolated from the Indian marine sponge Psammalplysilla purpurea. The structure of the compound was established by interpretation of their spectral data.
\end{abstract}

Keywords: Psammalplysilla purpurea, $N$-(\{3,5-dibromo-4-[3-(methylamino) propoxy]phenyl $\}$ ethyl) carbamic acid methyl ester (1), purpuramine-L (2)

\section{Introduction}

Marine sponges of the order Verongiidae are known to produced biogenetically related bromotyrosine derived secondary metabolites which are potent antibiotics. ${ }^{2-5}$ In continuation of our search for biologically active compounds from marine organisms ${ }^{6-8}$ we have investigated the sponge Psammalplysilla purpurea Carter (Verongiidae), collected from Gulf of Mannar, at Mandapam coast during February 2003. A literature survey revealed that the genus Psammalplysilla has yielded several bromo tyrosine derive metabolites namely psammaplysillins, ${ }^{9}$ purpuramines,${ }^{10}$ and macrocyclic bastadines. ${ }^{11}$

\section{Results and Discussion}

The $\mathrm{CH}_{2} \mathrm{Cl}_{2}$ : MeOH (1:1) extract of the freeze-dried sponge Psammalplysilla purpurea was subjected to gel filteration (Sephadex, $\mathrm{LH}-20, \mathrm{CH}_{2} \mathrm{Cl}_{2}: \mathrm{MeOH}(1: 1)$, followed by silica gel chromatography, eluting with step gradient of hexane-EtOAc mixtures to $\mathrm{MeOH}$, to afford 
known compounds 3,5-dibromo-4-methoxyphenylacetonitrile, 3-bromo-4methoxyphenylacetonitrile, ${ }^{8} 1$-hydroxyuracil,${ }^{13}$ thymidine, ${ }^{14}$ ergosterol, ${ }^{15}$ purpuramine-L $\mathbf{2}^{7}$ and a new compound $\mathbf{1}$.
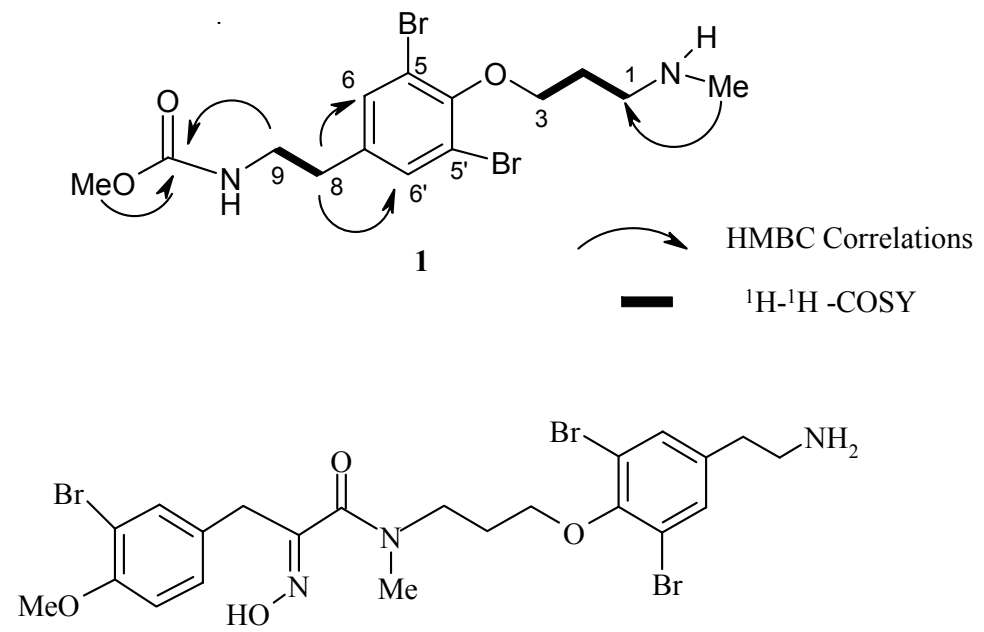

\section{Purpuramine-L}

Compound 1 was obtained as an optically in active brown semi solid. Its molecular formula was established as $\mathrm{C}_{14} \mathrm{H}_{20} \mathrm{Br}_{2} \mathrm{~N}_{2} \mathrm{O}_{3}$ by FABMS, which showed molecular cluster ion $[\mathrm{M}+\mathrm{H}]^{+}$ peaks at $\mathrm{m} / \mathrm{z} 423,425$, and 427 in a 1:2:1 ratio, suggesting the presence of two bromine atoms. The IR bands at 3310, 2950, 2795, 1713, 1540 and $1463 \mathrm{~cm}^{-1}$ indicated the presence of an amide carbonyl, and a secondary amine group in compound $\mathbf{1}$. The ${ }^{1} \mathrm{H}$-NMR spectrum of compound $\mathbf{1}$ displayed an aromatic signal at $\delta 7.44\left(2 \mathrm{H}, \mathrm{s}, 6,6^{\prime}-\mathrm{H}\right)$. Further its ${ }^{1} \mathrm{H}-\mathrm{NMR}$ spectrum displayed signals for five methylene groups at $\delta 4.08(2 \mathrm{H}, \mathrm{t}, J=7.0 \mathrm{~Hz}), 3.36(2 \mathrm{H}, \mathrm{m}), 3.28(2 \mathrm{H}, \mathrm{m}), 2.72$ $(2 \mathrm{H}, \mathrm{t}, J=7.0 \mathrm{~Hz})$, and $2.26(2 \mathrm{H}, \mathrm{m})$; an ester methyl group signal at $\delta 3.60(3 \mathrm{H}, \mathrm{s})$ and $\mathrm{N}$ methyl group signal at $\delta 2.76(3 \mathrm{H}, \mathrm{s})$.

The linear connectivity of the methylene groups was established by the ${ }^{1} \mathrm{H}-{ }^{1} \mathrm{H}$ COSY spectrum. In the ${ }^{1} \mathrm{H}-{ }^{1} \mathrm{H}$ COSY spectrum the signal at $\delta 2.26$ showed correlation with an oxygen bearing methylene at $\delta 4.08$ and with a methylene connected to the amine at $\delta 3.36$. Further, the two-methylene signals at $\delta 3.28$ and $\delta 2.72$ are found mutually coupled. From the study of ${ }^{1} \mathrm{H} \&$ ${ }^{13} \mathrm{C}$ - NMR spectral data, the two-methyl signals at $\delta 2.76$ and $\delta 3.60$ were assigned to an ester methyl of a carbamate [ $\delta 159.50(\mathrm{~s}), 52.48$ (q)] and to a methyl on nitrogen [ $\delta 33.95$ (q)], respectively. The structure of compound $\mathbf{1}$ was established by the study of heteronuclear multiple bond connectivity (HMBC) and nuclear overhause effect spectroscopy (NOESY) correlations. In its $\mathrm{HMBC}$ spectrum the $\mathrm{C}-1$ methylene protons at $\delta 3.36(2 \mathrm{H}, \mathrm{m})$ showed correlation with $\mathrm{C}-3$, $\mathrm{C}-2$, and to a N-methyl signal at $\delta 33.95$ (q). Further the C-9 methylene protons $\delta 3.28(\mathrm{~m})$ 
showed correlation with the carbamate carbonyl at $\delta 159.5$ and the C-7 aromatic carbon at $\delta$ 140.41. The methoxyl signal at $\delta 3.60$ showed correlation with the carbamate carbonyl group at $\delta$ 159.50 .

In the NOESY spectrum the C-1 methylene signal at $\delta 3.36(2 \mathrm{H}, \mathrm{m})$ showed correlation with methyl signal at $\delta 2.76(3 \mathrm{H}, \mathrm{s})$. The methylene signal at $\delta 2.72(2 \mathrm{H}, \mathrm{t}, J=7.0 \mathrm{~Hz}, 8-\mathrm{H})$, showed correlation with an aromatic proton at $\delta 7.44(2 \mathrm{H}, \mathrm{s}, 6,6$ ').

The foregoing spectral data established the structure of compound 1 as N-(\{3,5-dibromo-4[3-(methylamino) propoxy]phenyl\} ethyl) carbamic acid methyl ester (1).

Table 1. ${ }^{13} \mathrm{C}-(75 \mathrm{MHz}),{ }^{1} \mathrm{H}-\mathrm{NMR}(500 \mathrm{MHZ})$ and HMBC (500 MHZ) Data for Compound $\mathbf{1}^{\mathrm{a})}$

\begin{tabular}{cccc}
\hline Position & $\delta c($ mult.) & $\delta_{\mathrm{H}}$ & HMBC \\
\hline 1 & $48.14(\mathrm{t})$ & $3.36(2 \mathrm{H}, \mathrm{m})$ & $\mathrm{C} 2, \mathrm{C} 3, \mathrm{~N}-\mathrm{Me}$ \\
2 & $27.89(\mathrm{t})$ & $2.26(2 \mathrm{H}, \mathrm{m})$ & $\mathrm{C} 3, \mathrm{C} 1$ \\
3 & $71.55(\mathrm{t})$ & $4.08(2 \mathrm{H}, \mathrm{t}, J=7.0)$ & $\mathrm{C} 2, \mathrm{C} 1, \mathrm{C} 4$ \\
4 & $152.16(\mathrm{~s})$ & & \\
$5,5^{\prime}$ & $118.74(\mathrm{~s})$ & & $\mathrm{C} 5,5^{\prime}, \mathrm{C} 6,6^{\prime}, \mathrm{C}-8$ \\
$6,6^{\prime}$ & $134.36(\mathrm{~d})$ & $7.44(2 \mathrm{H}, \mathrm{s})$ & \\
7 & $140.41(\mathrm{~s})$ & & $\mathrm{C} 1$ \\
8 & $35.72(\mathrm{t})$ & $2.72(2 \mathrm{H}, \mathrm{t}, J=7.0)$ & $\mathrm{CO}$ \\
9 & $42.86(\mathrm{t})$ & $3.28(2 \mathrm{H}, \mathrm{m})$ & \\
$\mathrm{N}-\mathrm{Me}$ & $33.95(\mathrm{q})$ & $2.76(3 \mathrm{H}, \mathrm{s})$ & \\
$\mathrm{CO}$ & $159.50(\mathrm{~s})$ & & \\
$\mathrm{OMe}^{2}$ & $52.48(\mathrm{q})$ & $3.60(3 \mathrm{H}, \mathrm{s})$ & \\
$\mathrm{CD}_{3} \mathrm{OD}$ & & &
\end{tabular}

\section{Experimental Section}

General Procedures. Optical rotations were measured on a JASCO DIP-370 polarimeter. UV and IR spectra were recorded on Shimadzu-240 and Perkin-Elmer 240-C instruments, respectively. ${ }^{1} \mathrm{H}$ NMR (500 MHz) and ${ }^{13} \mathrm{C}$ NMR (125 MHz) spectra were recorded on a Varian Gemini $500 \mathrm{MHz}$ spectrometer using TMS as internal standard. Chemical shifts are reported in parts per million and coupling constants $(\mathrm{J})$ are expressed in Hertz. Mass spectra were recorded on a VG Auto Spec-M instrument.

Animal material. The sponge Psammaplysilla purpurea was collected from the Mandapam coast in the Gulf of Mannar, Tamilnadu, India, during February 2003. A voucher specimen (IIC564 ) is on deposit at the National Institute of Oceanography, Goa, India. 
Extraction and isolation. The freshly collected sponge specimens were soaked in $\mathrm{MeOH}$ at the site of collection and kept in $\mathrm{MeOH}$ until workup. The initial methanol was decanted and the sponge Psammaplysilla purpurea (1.0 wet weight $\mathrm{kg}$ ) was extracted with $1: 1 \mathrm{CH}_{2} \mathrm{Cl}_{2}-\mathrm{MeOH}$ (3 $\times 3 \mathrm{~L})$ at room temperature. The combined extract including the initial methanol extract was filtered and the solvent was removed under reduced pressure to give a predominantly aqueous suspension, which was partitioned between water and EtOAc. The EtOAc soluble portion was again concentrated under reduced pressure to give a dark brown gummy mass $(4 \mathrm{~g})$. This crude extract (4 g) was subjected to gel filtration chromatography (Sephadex LH-20, 1:1 $\mathrm{CH}_{2} \mathrm{Cl}_{2}$ $\mathrm{MeOH}, 47 \mathrm{~mm} \mathrm{X} 820 \mathrm{~mm}$ ) collecting 25 fractions $(25 \mathrm{~mL}$ each) followed by silica gel chromatography of selected fractions using a step gradient of hexane to hexane-ethyl acetate mixtures to $\mathrm{MeOH}$, to yield 3,5-dibromo-4-methoxyphenylacetonitrile (40mg), 3-bromo-4methoxyphenylaceto-nitrile (50 mg), 1-hydroxyuracil (30 mg), thymidine (50 mg), 24-methylene cholesterol (100 mg), compound 1 (20 mg) and purpuramine L (2, $25 \mathrm{mg})$.

$N$-(\{3,5-dibromo-4-[3-(methylamino) propoxy]phenyl $\}$ ethyl) carbamic acid methyl ester (1): Optically inactive semi solid (20 mg), IR (KBr) $v_{\max } 3310,2950,2795,1713,1540$, and $1463 \mathrm{~cm}^{-}$ 1; UV (MeOH), $\lambda_{\max }(\log \varepsilon) 250.0$ (2.210); ${ }^{1} \mathrm{H}$ NMR (500 MHz, CD $\left.{ }_{3} \mathrm{OD}\right)$ and ${ }^{13} \mathrm{C} \mathrm{NMR}(75$ $\left.\mathrm{MHz}, \mathrm{CD}_{3} \mathrm{OD}\right)$ see Table 1; positive FABMS $m / z$ 427, 425, and $423\left[\mathrm{MH}^{+}\right]$, in a 1:2:1 ratio; HRFABMS $m / z 425.1405$ (Calcd for $\mathrm{C}_{14} \mathrm{H}_{20} \mathrm{Br}_{2} \mathrm{~N}_{2} \mathrm{O}_{3} m / z$ 425.1398).

\section{Acknowledgments}

We are thankful to Dr. P. A. Thomas, Central Marine Fisheries Research Institute, Vizhinjam, Thiruvananthapuram, India, for identifying the sponge, the Department of Ocean Development, New Delhi, India, for financial assistance, Dr. J. S. Yadav the Director IICT, for their constant encouragement, and CSIR, New Delhi for providing fellowships to K. R. and A. V. R.

\section{References}

IICT Communication No: 040517

1. This paper is dedicated to Dr. A.V. Rama Rao to mark his $70^{\text {th }}$ birthday and in recognition of his outstanding contributions to the chemistry of Natural Products.

2. Bergquist, P.R.; Wells, R.J. In Marine Natural Products. Chemical and Biological Perspectives, Scheuer, P. J., Ed.; Academic Press: New York, 1985; Vol. 5, pp 150.

3. Tsuda, M.; Shigemori, H.; Ishibashi, M.; Kobayashi, J. Nat. Prod. 1992, 55, 1325.

4. Carney, J.R.; Scheuer, P.J.; Kelly- Borges, M. J. Nat. Prod. 1993, 56, 153.

5. Faulkner, D. J. Nat. Prod. Rep. 1998, 15, 113, 158, and references cited therein.

6. Venkateswarlu, Y.; Venkatesham, U.; Rama Rao, M. J. Nat. Prod. 1999, 62, 893.

7. Venkateswarlu, Y.; Rama Rao, M.; Venkatesham, U. J. Nat. Prod. 1998, 61, 1388. 
8. Venkateswar Goud, T.; Srinivasulu, M.; Niranjan Reddy, V. L.; Vijender Reddy, A.; Venkateswarlu, Y. Chem. Pharm. Bull. 2003, 51, 990.

9. Venkateswarlu, Y.; Ramadas, C. J. Nat. Prod. 1995, 58, 1087.

10. Rotem, M.; Carmely, S.; Kashman, Y. Tetrahedron 1983, 39, 667.

11. Yagi, H.; Matsunaga, S.; Fusetani, N. Tetrahedron 1993, 49, 3749.

12. Pettit, G. R.; Butler, M.S.; Bass, C.G.; Doubek, D.L.; Williams, M.D., Schmidt, J.M.; Pettit, R.K.; Hooper, J. N. A.; Tckett, L. P.; Filiatrault, M. J. J. Nat. Prod. 1995, 58, 680.

13. Kobayashi, J.; Honma, K.; Sasaki, T.; Tsuda, M. Chem. Pharm. Bull. 1995, 43, 403.

14. Ohigashi, H.; Kaji, M.; Sakaki, M.; Koshimizu, K. Phytochemistry 1989, 28, 1365.

15. Levene, P. A.; London, E.S. J. Biol. Chem. 1929, 83, 793.

16. Itoh, T.; Sica, D.; Djerassi, C. J. Chem. Soc., Perkin Trans I 1983, 1, 147. 